\title{
U. S. Professional Development Experiences with Faculty and Undergraduate Students in Kosovo
}

Sally R. Beisser

Prof., Distinguished Professor, Corresponding author, Drake University, USA, sally.beisser@drake.edu

\section{Jennifer Thoma}

Asst. Professor, Drake University, USA, jennifer.thoma@drake.edu

In this qualitative case study, professional development of pedagogical strategies was In this qualitative case study, professional development of pedagogical strategies was presented to 44 university professors and 33 undergraduate students representing two Eastern European universities. This study was part of an international partnership between one U.S. Midwest private university and two partnership universities in Kosovo. Researchers conducted a two-day pedagogical workshop in each university setting. Participants in one university represented the Faculty of Medicine, Education, and Language professors. The other university group included English Language and Literature undergraduate majors. Using survey research methods of questionnaires and interviews, data were collected using a pre-workshop questionnaire to inform the workshop content, post-workshop survey, and participation discussion, follow up interviews, and researcher reflections. Researchers presented a series of workshops on best practices in student engagement, questioning strategies, formative reflective assessment, and representing to learn in each university setting. Results revealed participants from both universities were a) positive about learning new pedagogical strategies and b) implementing new teaching practices as a result of the workshop interventions. These findings suggest building positive professional partnerships for professional development results in valuable changes to professional practice. Future research should focus on long-term benefits of such partnerships, specifically on how workshops may continue to inform professional practice.

Keywords: professional development, student engagement, questioning, assessment strategies

\section{INTRODUCTION}

Ongoing, high quality professional development and educator training are required to ensure that instructors have the tools they need to deliver the most effective practices for their students. Successful educator training institutions have several common features (Darling-Hammond, 1999) that include a common vision of good teaching; well-defined standards of academic practice; rigorous core curriculum; use of problem-based methods; supervised clinical experiences; and strong relationships with students.

Determining effective outcomes from professional development has been proven difficult (Hattie, 2009). Most teachers can take workshop training back to the classroom when training includes presentation of theory, demonstration of new strategy, initial practice in workshop, and prompt feedback about their efforts (Showers, Joyce, \& Bennett, 1987).

Citation: Beisser, S. R., \& Thoma, J. (2021). U.S. Professional Development Experiences with Faculty and Undergraduate Students in Kosovo. Anatolian Journal of Education, 6(1), 1-16. https://doi.org/10.29333/aje.2021.611a 
Additionally, professional training that occurs across countries requires special considerations. Collaboration for international professional development should include educators' voices and collaboration between different social, cultural, and teaching institutions. Providing quality professional development requires several vital features, including engagement and active learning, coherence with school standards and goals, and content focus (Desimone, Poerter, Garet, Yoon, \& Birman, 2002). In this study, two U.S. researchers provided research-based professional development to university faculty and preservice teachers in the recently established country of Kosovo. The researchers used information from a research brief, provided by the European Training Foundation (EFT), with responses from over 250 educators to assess their experiences with continuing professional development (Likaj, 2016). Findings in this report suggest that professional development planning at the institutional level is not reliable and does not inform professional development; administrators are not trained to identify needs or support professional development; and educators must identify their own pedagogical needs. Educators report wanting more feedback on their teaching practices. This research brief was used to inform the initial survey sent out to potential participants for the current study.

In this study, two U.S. researchers conducted a two-day workshop in two separate universities in Kosovo. Considerations were given to the cross-cultural nature of the professional development, needs of the participants, and the perceived success of the workshops. Thus, the research question for this study was "to what extent does a two-day workshop by U.S. professors impact teaching and learning practices of participants from two separate universities in Kosovo?"

\section{Literature Review}

\section{Professional Development}

Research in the area of professional development continues to grow (Lawless \& Pellegrino, 2007; Polly \& Hannafin, 2010). In a meta-analysis of over 200 research studies, Showers, Joyce, and Bennett (1987) found that what teachers think determines what teachers do; almost all teachers can take training back to classroom when training includes presentation of theory, demonstration of new strategy, initial practice in workshop, and prompt feedback about their efforts. Teachers are likely to keep and use strategies if they receive coaching from peers or experts while trying new ideas in classroom. These findings were later confirmed by Joyce and Showers (2002) when they found that training components and attainment of outcome are provided in rough estimates. When teachers participated in the study of theory through professional development, demonstration of new strategies, and feedback, teachers had an increase of 95\% knowledge, 95\% skill, and 95\% transfer to classroom practice.

In a synthesis of over 800 meta-analyses relating to student achievement, Hattie (2009) states that it is difficult to determine the effectiveness of professional development due to the manner in which outcomes are measured. For example, many studies measure the changes in teacher practice rather than student outcomes. The overall effect size for professional development is $d=0.62$ (Hattie, 2009). While effect sizes were not reported out for each category, the four types of professional development that were found to have the greatest impact on teacher outcomes were observation of classroom methods, microteaching, video/audio feedback, and practice. Each of these areas focus on examining what is happening for students in the classroom.

In support of Hattie's findings of focusing on what is happening for students in the classroom, Joyce (2004) states that school improvement can only be achieved through continuous, increasingly "concrete and precise talk about teaching practice" (p. 76). The practice Joyce is referring to is often called functioning as Professional Learning Communities. 


\section{Global Professional Development}

Defining teacher professional development and measuring teacher quality across international settings is a complex process, especially given our assessment-driven global society (Liu, 2015). While using student achievement data across international settings has been used to analyse teacher effectiveness, these measures do not provide useful data across cultures. Liu (2015) called for a culturally embedded conception of achievement and assessment in order to enable international collaboration on professional development.

Internationally, incorporating teachers' voices in their professional growth, especially in terms of building professional communities of practice, has become the trend (Goldberg, 2019). This practice allows teachers to voice their needs as they solve problematic issues in the classroom. Top-down approaches to professional development often leave teachers' voices out (Eltemamy, 2019). Inviting teachers to be leaders is one way to include teachers' voices in professional development (Qanay, Anderson-Payne, Ball, Barnett, Kurmankalova, Mussarova, Kenzhetayeva \& Tanayeva, 2019).

Collaboration between different cultural, social, and educational institutions can provide challenges. Rudge (2018) explains that differences in organizations' philosophies, interpersonal relationships, and cultural values can affect collaboration between professionals. Mutual trust is required, that includes confidence in one's abilities, as well as confidence in the abilities of others.

\section{Theoretical Framework}

This study is grounded in Vygotsky's work on Social Cognition Theory (1978). This theory fundamentally examines the development of thought processes in children. In this study, Vygotsky's theory is applied to adult thinking and learning, although this was not the true intent of his work (Daniels, Cole, \& Wertsch, 2011). According to Social Cognition Theory, "...human mental functions must be viewed as products of mediated activity. The role of mediator is played by psychological tools and means of interpersonal communication," (Vygotsky, 1986, p. xxxix). Psychological tools include gestures, sign systems, mnemonic techniques, and decision-making systems. In the current study, the workshops as professional development are situated as the means for teacher learning and planning. As such, they provide opportunities for teachers to learn from one another, as well as share their knowledge. Vygotsky's (1978) concept of the zone of proximal development refers to the distance between actual developmental level in children as determined by independent problem solving and the level of potential development when problem solving along with an adult. In respect to Vygotsky's (1978) zone of proximal development these social interactions provide a means for a more knowledgeable other (e.g., workshop facilitators and peers) to guide others to a deeper understanding of pedagogical strategies (student engagement, questioning strategies, formative reflective assessment, and representing to learn).

\section{Professional Development Workshops}

Accordingly, workshops developed for this study, were a result of prior communication and collaboration with key university administrators in Kosovo. Workshop presentations focused on four different areas: student engagement; questioning strategies; formative reflective assessment; and representing to learn.

\section{Student-centered Learning}

While many teachers "teach how they were taught," higher education instructors are more likely to use traditional teaching methods such as teacher-directed procedures, explicit rules, didactic instruction, lectures, whole group instruction, individual work, predetermined curriculum, "right" answers, delivery of curriculum, reliance on summative assessment, and limited use of technology (Cadiero- 
Kaplan, 1999). Higher education instructors, in general, lack formal training in teaching strategies of any kind. Therefore, they tend to emulate the teaching style they experienced as students themselves (Oleson \& Hora, 2013). Teaching strategies of higher education instructors tend to be defined by traditional methods that are instructor-centered, not student centered.

Notably, student-centered learning includes interactive delivery systems inviting student engagement, active learning, meaning-making, inquiry-based discussion, novel approaches, cooperative and collaborative learning, open-ended assignments, formative assessment, and constructivist use of technology (Cadiero-Kaplan, 1999). The student-centered instructor is a "guide on the side," not a "sage on the stage." As such, students are active learners seeking information and applying knowledge in a dynamic learning process. Student-centered learning is gaining interest in higher education. Moving towards student-centered learning can lead to greater success for students and increased job satisfaction for teachers (Fiala, 2018). Therefore, student-centered learning may lead to higher levels of student achievement, content knowledge, skill acquisition, retention, and application of information.

\section{Best Practices}

The workshops for this study were developed based on what has been deemed as "best practices" (Zemelman, Daniels, \& Hyde, 2012). The use of best practices in education stems from common big ideas found in the most prominent education research (Zemelman, et al. 2012). Research-based best practices in higher education now necessitate more student-centered learning and less teacher-centric activities. Examples of student-centered learning include hands-on activities, development of students' curiosity, cooperative and collaborative activity, and formative assessments to guide learning. These practices call for less "seat work," less time memorizing facts and details, and less use of standardized tests. Based on feedback from a pre-survey sent to participants, faculty and students were hoping to learn pedagogical strategies to engage students in learning. Therefore, the pedagogical workshops planned for University A and University B concentrated on best practices, such as student engagement, questioning strategies, formative reflective assessment, and representing to learn.

\section{Student Engagement}

Decades of research on student engagement support the impact of positive relationships, motivation, classroom engagement through active learning, mastery learning, timely interventions, and effective assessment in order to maximize student learning in the classroom (Christenson, Reschly, \& Wylie, 2013). Consequently, content knowledge, skill development, and positive attitudes toward learning are enhanced in a teaching and learning environment promoting student learning.

\section{Questioning Strategies}

Researchers have suggested that questioning strategies should be built on good guiding questions or essential questions to focus instruction, discussion, and assessment (Traver, 1998). Rechetti and Sheerin (1999) recommend student-centered inquiry that encourages students to "ask the right questions." Sternberg (1994) challenges students to not only answer questions, but to question answers.

\section{Formative Reflective Assessment}

Formative assessment is a type of assessment that generates feedback to improve learning (Saddler, 1998). In order to advance learning and motivate students, both teachers and students must be aware of learning targets, how students are performing against the targets, and next steps students must take to achieve them (Hattie, 2012). 


\section{Representing to Learn}

There are a variety of ways in which learners obtain content (Tate, 2012). Brain research supports the rationale behind why some strategies work better than others (Sousa, 2006; Wolfe, 2001). Different ways of representing learning were presented in this professional development, such as writing to learn, graphic organizers, diagrams, projects, and demonstrations.

This study examines the extent of impact of a two-day pedagogical workshop in two international settings based on best practices in education: student engagement, questioning strategies, formative reflective assessment, and representing to learn.

\section{METHOD}

This qualitative case study (Creswell, 2013) investigated the impact of pedagogical training in higher education. Case study design and analysis, based on the work of Phondej, Kittisarn, \& Neck, Philip (2010), included (1) Justification for the qualitative research paradigm and research methodology, (2) Justification for the case study method, (3) Criteria for judging the quality of case study design (4) Designing the case study, (5) Criteria for selecting a case design, (6) Data collection, and (7) Case study analysis to determine our findings. This case study was carried over a seven-month timeframe from the original design to final analysis.

Using data from the pre-workshop electronic survey, the researchers designed a two-day workshop for full-time faculty of instruction of medicine, education, and languages at University A and graduating English Language and Literature seniors at University B. The overarching research question investigated "to what extent does a two-day pedagogical workshop intervention by U.S. professors impact teaching and learning practices of participants in two international settings in Kosovo?" The 44 professors and 33 undergraduate students were selected using purposeful sampling (Salmons, 2015). Participants were selected as a result of their willingness to respond to an invitation extended by Kosovo key administrative contacts from University A and University B. Criteria for selection was based on interest, availability, and commitment to participate in a two-day professional development workshop at each university. Table 1 indicates that 26 males and 18 females from University A participated. Table 2 represents 6 males and 27 females representing the undergraduate respondents. The two researchers worked in tandem to present two workshops for the professors in University A using English with translation to Albanian while two workshops for the undergraduate students in University B were presented in English.

\section{Relationship with Kosovo Universities}

There are seven public universities and 29 private colleges in Kosovo. Our partnerships with two of these universities stemmed from our campus International Center initiatives in collaboration with Kosovo higher education. From the researchers' university, a School of Education international committee chair worked to establish connections to two of the smaller, public universities in Kosovo with degree programs somewhat similar to our small Midwest university in the United States.

The first university partner (University A) is a public university of 3200 students with three Faculties; the Faculty of Education with two study programs - Preschool and Elementary; the Faculty of Medicine with two study programs - Nursing and Midwifery; the Faculty of Philology with three study programs - Albanian Language, Albanian Literature and English Language and Literature. The programs are labor-market-oriented. After completion of their studies, graduates are ready to find work in public and private institutions and open their businesses.

The second university partner (University B) is a public university of 10,000 students. Faculties were represented from the following departments: Economics with Business Administration and 
International Management; Law-Juristic; Computer Science with Software Design and Instructional Technology; Education with Primary School and Pre-Primary School Programs; Philology with Albanian, English, German and Turkish Language and Literature; and Life and Environmental Sciences with Agribusiness and Forestry and Environmental Sciences. Similarly, upon graduation, students were poised for employment in public and private institutions and business occupations.

Kosovo is a country of approximately two million people. Their independence as a nation was established in 2008 and maintains a long-standing relationship with our Midwest state in two ways. First, over 700 National Guard men and women from our state were instrumental in restoring property and providing support to the Kosovar people following the ethnic conflicts and bombing from Serbian forces prior to their national independence. The [State] Kosovo National Guard Partnership has a long-term goal of developing security and fostering mutually beneficial interests across all levels of society. Establishing a strong relationship with Kosovo, this partnership represents a critical step toward reform, development, and security in Kosovo ([State] Register, 2015). This strong relationship resulted in our sister state agreement.

The sister state relationship with Kosovo, since 2018, now includes five sister city partnerships within our state of three million people. This organization, based in the capital city of our state, is a volunteer-driven non-profit group whose mission is to build sustainable international partnerships connecting our state to world communities. Our state has a history of citizen diplomacy with dedicated volunteers and staff who are proud to continue this legacy with nine international partners (Sister States, 2013).

Measuring the effectiveness of professional development is a complicated process. One way to manage the complexity of this is to focus on the critical features of a professional development activity, rather than the structure (Desimone, 2009). Typical methods for assessing the effectiveness of professional development are observations, interviews, or surveys. According to Desimone (2009), biases exist with each of these methods. However, it is important not to dismiss these methods for their biases. Using these methods is appropriate, given the nature of our research questions.

Data collection for this case study included an initial an online electronic Qualtrics $\subset$ survey, translated in Albanian for professors in University A. The survey was delivered in English to the students in University B. Through this survey we could explore topics of interest regarding pedagogical training and teaching methodologies before conducting the workshops. The four topics for the workshops were determined from this survey.

Workshop training materials included four interactive powerpoint presentations, based on content literature of best practice (Zemelman, Daniels, \& Hyde, 2012) to introduce participants to theory and examples of student engagement, questioning strategies, formative assessment, and ways to represent learning. Supplemental handouts, such as templates for assessment rubrics and levels of questioning, in support of the powerpoint presentations to engage participants in discussion and application of content. Presenters shared techniques for engaging student in the learning process such as ice breakers, interactive games, and ways of helping participants think critically about pedagogy. During the workshops each presenter provided opportunities for clarification and time to ask questions during and after each session.

Immediately after presenting the final workshops, we collected post-workshop paper-pencil surveys from University A professors, then conducted an exit interview with the key administrator at University A. From University B students, we collected narrative comments based on summative discourse with participants after the final workshops. Finally, we conducted follow up interviews, seven months later, with the key administrators from both University A and University B. 
Data analysis was conducted through the use of within-case and cross-case analysis (Yin, 2016) to identify key themes. Validation of data included triangulation, member checking, narrative descriptions (Creswell, 2013), and researcher reflexive journaling. Findings were recorded in a mixedmethods structure to provide numerical information from the surveys and narrative responses from participants in this study.

\section{Researcher Positionality}

As education professors in a U.S. Midwest small private university, teaching multiple courses in Curriculum and Pedagogy, Literacy, Assessment, and Teacher Education Methods, the authors have academic insights into pedagogical training and teaching practices for effective classroom engagement, learning, and assessment. We conduct peer observations to provide feedback on classroom teaching methodologies to gain better understanding of pedagogical practices of our peers. We both have extensive background in adult learning theory (Knowles \& Swanson, 2015) and present to educators on effective pedagogical practices.

\section{Case Study}

Case studies focus on in-depth descriptions of an individual or group of individuals, using numerous data collection techniques, including interviews, observations, and document review (Creswell, 2013). A key characteristic of case studies is that their boundaries are clearly defined. Case studies are bound by a specific time, place, or event. One form of case study is a collective case study, or multi-case study, in which multiple cases are used to represent the issue (Bogdan \& Biklen, 2007; Creswell, 2013). Each university group of participants in this study served as a case for the multi-case study. The study is bound by participant selection from a group of individuals that share the common characteristics of members of a group of full-time teaching faculty at one university in Kosovo and full-time fourth-year students at the other university in Kosovo. Yin (2016) suggests that collective case studies should replicate experiences. In this case, participants experienced the same pedagogical training with content, topics, and procedures that were replicated with each group.

This multi-case study (Bogdan \& Biklen, 2007; Creswell, 2013) was bound by participant selection from the pool of over 40 faculty of medicine, education, and language instructors at University A and 60 students of English Language and Literature at University B in Kosovo. Approximately 100 potential participants met the criteria for this study.

\section{Research Setting}

Qualitative research is best conducted in the naturalistic setting of the participants (Creswell, 2013). Therefore, we met on the campus of each of our two participating universities at Kosovo. The site of our Kosovo professional development with professors in University A was in a university classroom with whiteboards, where rectangular tables were situated in a rectangular formation. Participants were provided headphones to hear the translation from English to Albanian using microphones to propose questions and responses. Each of the researchers had headphones to allow the translators to hear our presentations and then translate in Albanian. We presented simultaneous workshops each day to allow smaller groups of participants to listen, learn, ask questions, and interact with us as much as possible. The research setting in University B was in a large university classroom with green chalkboards, access to technology, no headphones or microphones, and student participants seated in long tables in front of the presenters.

\section{Participants}

Participation in this research study was initially extended to faculty $(\mathrm{N}=44)$, including $\mathrm{Ph} . \mathrm{D}$. students $(\mathrm{N}=14)$ and undergraduates $(\mathrm{N}=60)$. Purposeful sampling methods (Salmons, 2015) were used in 
participant selection, including the convenience of a preselected population with whom our key leaders were working in each of these universities. The selection criteria of participants included full-time faculty and full-time students in each of these two universities, thus establishing homogeneity of group membership as either professors or students.

Table 1

Description of workshop participants in university A

\begin{tabular}{lllllrr}
\hline $\begin{array}{l}\text { University Faculty } \\
\text { Total }\end{array}$ & $\begin{array}{l}\text { Ph.D. } \\
\text { Candidates }\end{array}$ & $\begin{array}{l}\text { Faculty of } \\
\text { Medicine }\end{array}$ & $\begin{array}{l}\text { Faculty of } \\
\text { Education }\end{array}$ & $\begin{array}{l}\text { Faculty of } \\
\text { Languages }\end{array}$ & Male & Female \\
\hline 44 & $31 \%$ & $29 \%$ & $38 \%$ & $31 \%$ & $59 \%$ & $41 \%$ \\
\hline
\end{tabular}

Table 2

Description of workshop participants in university B

\begin{tabular}{lllll}
\hline $\begin{array}{l}\text { Undergraduate Student } \\
\text { Total }\end{array}$ & $\begin{array}{l}\text { Have Teaching } \\
\text { Upon Graduation }\end{array}$ & $\begin{array}{l}\text { Began Masters } \\
\text { Program Upon Graduation }\end{array}$ & Male & Female \\
\hline 33 & $15 \%$ & $84 \%$ & $18 \%$ & $82 \%$ \\
\hline
\end{tabular}

\section{Pre-Workshop Survey}

The researchers developed survey questions prior to the pedagogical workshops in order to determine the needs of the participants in each setting. Research-based content from pedagogical literature provided a framework for the presentations, as well as formulating the questions on the survey. The 26-question survey was developed by the researchers using open-ended questions, a 5-point Likert scale (Likert, 1932), and a sliding scale of responses. Likert scales are commonly used in survey research in order to collect opinion data. In attempting to query the respondents at both University A and University B, we addressed the features and factors of the 26 questions to improve the validity of the scale and invite narrative comments. Ideally, if surveyed, again, the data would reflect the true opinions of the population we surveyed.

Questions evolved from a variety of categories. The aim of the survey was to create a knowledge base and interest level relative to the professional development topics we intended to present. The language used in questions was carefully considered so both professors and students would feel comfortable sharing their thoughts and opinions. Survey terms should be defined for common understanding (Fink, 2013). Informed consent allowed participant permission to complete the survey prior to the workshops. To clarify any questions about the survey, participants communicated directly with our university A and B liaisons in Kosovo.

\section{Survey Delivery}

The survey design resulted from pre-workshop inquiry from the U.S. researchers who communicated with the key university leaders in Kosovo for this study, clarifying topics of interest for the professional development workshops in each of the two universities. These key individuals provided ideas of interest and need within their educational program settings whether from faculty of instruction (University A) and undergraduates (University B). Following ideas expressed in this communication response, the researchers prepared a survey regarding participant interest and experience in four areas of interest and concern. that included student engagement, questioning strategies, formative assessment, and ways to represent learning. Therefore, a pre-workshop online a Qualtrics $\subset$ survey addressed these four major areas of interest.

As a result, the online survey was developed by the U.S. researchers to explore these four topics. A link to the online survey was sent from our university contacts to potential participants through an email message that was directed to their work and student university email addresses. Qualtrics $\subset$ can anonymously track participants provide translation in the Albanian language for the professors. 
Surveys were completed before our arrival in Kosovo. In University A, our partnership professor edited the questions to make sense in Albanian academic language. The undergraduate students from University B took the survey in English as they studied English Language and Literature. Importantly, participant responses from the preworkshop online Qualtrics $\subset$ survey helped the researchers know the topics of interest and levels of interest before delivery of workshop content.

\section{Timeframe}

Our online survey was launched a week before we arrived in Kosovo and remained open during the time period we were presenting. The survey closed one week later after our workshop was completed. It was important that the participants responded to our questions before our workshops to determine interest and motivation to implement pedagogical strategies. However, we did not receive responses from participants in time to tailor their responses to our questionnaire. Nevertheless, we had the sense from each of the university leaders that they were excited about our presentations.

\section{Semi-structured Interviews}

The two key leaders, representing each university, were interviewed after the experience using Seidman's (2013) technique for a semi-structured interview with before, during, and follow up conversations. While informal information gathering questions helped us prepare our work, conversations throughout the workshops in the institution helped us inform our work. We implemented a follow-up set of questions as an interview guide, following our return. We engaged in a flexible interview process, allowing our key leaders at each university to reflect on their impressions while allowing us to change questions based on their responses or questions (Bogdan \& Biklen, 2007).

\section{Reflexive Journaling}

Qualitative researchers can supplement survey or interview data with additional insights from the reflection that provide background information regarding the research process (Bogdan \& Biklen, 2007; Mertens, 2010). Both researchers kept reflective journals of our experiences, made notes on our workshop interaction, and compared our journals with one another at the end of each presentation day.

\section{Data Analysis}

Creswell (2013) suggests there is not one single way to analyze qualitative data, but instead, it is an iterative, eclectic process. Accordingly, we simultaneously collected, analyzed, and reflected on our data points over seven months through organizing our data using the online and hard copy documents; reading and "memoing" notes, journaling, and interview transcripts; and interpreting the data seeking themes of meaning.

Data analysis included corroboration from multiple sources of evidence in addition to insights from both researchers and the key leaders at each university. Data were triangulated by analyzing the responses from all participants and data sources in order to reduce our researcher bias and increase the truthfulness of the process and the outcomes (Anfara, Brown, \& Mangione, 2002).

The data analysis process included reading the surveys from University A independently then comparing thoughts and insights collaboratively. We tallied all responses from the 10 survey questions regarding 1) workshop objectives, 2) participation, 3) topics, 4) organization, 5) materials, 6) usefulness, 7) preparedness of trainers, 8) training objectives, 9) time allotment, and 10) facilities. The responses were converted into percentages. Follow up narrative responses about what participants "like best, what could be improved, interest in future training, additional aspects for the future, and additional comments," were analysed for overall feedback. The follow up interview with the key administrator from University A was audio recorded, downloaded for verbatim quotes, and analysed for content, insights, and perspectives directly from her interactions and conversations from the 
respondents. Both participant quotes and the key leader quotes were included in this document. The researchers included our workshop presentation and journaling notes to support workshop findings.

University B data points were distinguished by the post workshop summative discussions directly with the pre-service students who expressed their opinions to each researcher. We wrote down their comments during these discussions to capture their reactions and insights. A follow up email asking about the relevance and applicability of the workshop provided additional feedback to support our findings. A follow up interview with the key administrator from University B was also audio recorded, downloaded for verbatim quotes, and analysed for content, insights, and perspectives directly from his interactions and conversations from the respondents.

Both participant quotes and the key leader quotes were included in the final document. The researchers included our workshop presentation and journaling notes to support workshop findings. Finally, we refined describing, representing and reporting our findings with University A and University B quotes, narratives, and visuals such as tables within the final paper.

\section{FINDINGS}

Data from post workshop participant surveys, semi-structured interviews with key administrative leaders, and reflexive journals elicited two major findings including a) participants from both settings were positive about learning new pedagogical strategies and b) participants are implementing new teaching practices as a result of the workshop interventions.

\section{Post Workshop Survey Results}

Data from University A were collected in the form of a Likert Scale to determine the overall usefulness of participants' time in the workshops. Table 3 shows how participants, who completed the survey, perceived the usefulness of the workshop:

Table 3

University A participants' ratings of workshop

\begin{tabular}{|c|c|c|c|c|c|}
\hline Survey Statement & Strongly agree & Agree & Neutral & Disagree & Strongly disagree \\
\hline The objective of the training was clearly defined & $82 \%$ & $18 \%$ & & & \\
\hline Participation and interaction were encouraged & $73 \%$ & $27 \%$ & & & \\
\hline The topics covered were relevant & $61 \%$ & $36 \%$ & $3 \%$ & & \\
\hline The content was organized and easy to follow & $66 \%$ & $34 \%$ & & & \\
\hline The materials distributed were helpful & $79 \%$ & $18 \%$ & $3 \%$ & & \\
\hline This training experience will be useful in my work & $68 \%$ & $30 \%$ & $2 \%$ & & \\
\hline The trainers were well prepared & $94 \%$ & $6 \%$ & & & \\
\hline The training objectives were met & $41 \%$ & $54 \%$ & $5 \%$ & & \\
\hline The time allotted for the training was sufficient & $43 \%$ & $36 \%$ & $21 \%$ & & \\
\hline $\begin{array}{l}\text { The meeting room and facilities were adequate } \\
\text { and comfortable }\end{array}$ & $9 \%$ & $43 \%$ & $39 \%$ & $9 \%$ & \\
\hline
\end{tabular}


The first finding revealed that participants from both universities were positive about learning new pedagogical strategies as a result of the professional development workshops. As noted in Table 3 there were seven categories that received the most positive responses from University A. Those areas were a) trainers were well prepared, b) objectives of the training were clear, c) distributed materials were helpful, d) participation and interaction was encouraged, e) training experiences will be useful in their work, f) content was organized and easy to follow, and g) pedagogical topics were relevant to participants. Clearly, the workshop information was novel to the participants and they expressed positive perceptions of pedagogy. With respect to areas with less positive responsivity, knowing if "training objectives were met" would not be realized until pedagogical strategies were implemented in their future teaching. We could not measure this objective immediately following the workshop. Next, responses suggested the "time allotted for training was not sufficient." Finally, regarding "meeting room and facilities," this was a factor we could not control. However, responses in Table 3 reveal overall satisfaction with pedagogical professional development.

Qualitative narrative comments from University A participants at the end of the survey supported finding one. One participant wrote that the training was "helpful and aspiring" while another stated it was "informative and motivational." They specifically commented positively on the "strategies, activities, materials, technology enhanced projections, interactivity" of the sessions, and the trainers. Participants commented on the "preparedness, friendliness, and abilities" of the trainers. Every single one of the participants said they would participate in this training if they had another chance.

Pre-service students in University B did not fill out this survey, but preferred engaging in discussion about the workshops. Edona (all names pseudonyms) replied, "This workshop has helped me improve my teaching by pushing me to think about best teaching strategies for my classes. I try to ask the right questions...to guide my students to the right questions. I prepare activities at the end of the class in order to see what was remembered from the lesson and what needs more work." I learned that "formative reflective assessment, being able to assess students during the learning process, is very helpful for both the teacher and the students." Lendita stated, The workshop was a helpful guide for people who aspire to be teachers. Every part was helpful and very well organized. The methods of teaching, especially the charts, were one of my favourites...the way we should approach teaching, taught me a lot." Valmira summarized, "This workshop was very helpful because I learned new strategies...new things that can be used in classrooms such as new games, new strategies on how to make pupils or students more active and prepared. For students it is not enough only to read or hear something, they need to do something with that knowledge and to understand that. Writing is one of the best strategies, writing an essay, being able to come with new ideas while the topic is introduced. I would use this strategy [representing to learn] in my classroom." Arban found the workshop powerpoints and handouts useful. Ezra concluded, "I believe that the general knowledge and skills we got from this training can be quite helpful if we, as young teachers, apply them in our activities with students." Overall, students found value in the workshop content, as well as interaction with the professors who presented the two-day sessions.

\section{Post Workshop Key Administrator Interviews}

Interviews were conducted with two key administrators from University A and University B seven months after completing the training. After analysing the data, two key findings arose. Participants are trying new pedagogical strategies according to the comments below.

\section{Trying New Pedagogical Strategies}

One finding that emerged from the data was that participants from both universities were engaged in using the new pedagogical strategies. From University B, students who had recently graduated reported, "The ones who got their job, said that they have already incorporated some of the teaching 
techniques strategies into their own teaching plans." Other students, who had not planned on entering the teaching field immediately reported, they "found the workshop very, very useful in a number of courses that they are attending in their Masters of Arts (MA) studies."

From University A, the key administrator reported, "Many of them [participants] said they try to involve new things that they learned from you, which they applied in their lectures." They learned new methodologies that had "improved their practice of teaching...especially on the new methods and techniques that were discussed in the workshops."

While not all of the learning from the workshops was new, it was a good refresher for some. As stated by the key leader from University A, "They're saying that for Faculties of Education and Faculty of Languages, the workshop was to refresh their knowledge on their teaching, while for the Faculty of Medicine, everything was novel, because they did not have experiences for learning new teaching methodologies." For example, participants from University A and University B both shared their appreciation of practicing Questioning Strategies immediately after the workshop. These comments were made directly to the presenter indicating enthusiasm of the content. Another example took place during the Formative Reflective Assessment Workshops for University A and University B. During the workshops, participants were asked to create an activity which they could immediately apply the strategy within their own context. After sharing out different ideas, participants stated that, while they were aware of formative assessment practices, taking time to think through different ways to apply the strategy helped them to think of changes they could make immediately to their pedagogical practices.

The overall goal of professional development is to improve student learning. While this study did not measure student achievement, participants reported that implementation of strategies from the workshops improved learning for students. One of the key leaders from University A stated, "I got some feedback, which they [the participants] wrote about. Many of them, tried to involve those things, new things that they learned from you, which they included in their lectures." Feedback from the key leader also indicated that participants "implemented new methodologies when students are writing, which improved their practice of teaching writing, resulting in student success."

\section{DISCUSSION}

Methods for assessing the effectiveness of professional development, which are commonly used are observations, interviews, or surveys. Biases exist with each of these methods (Desimone, 2009). While using student improvement data would be one of the most effective means of measuring successful professional development, this was neither practical nor possible for this study. By determining, through participants' voices using surveys, the usefulness of the workshops, as well as post-semistructured interviews, we were able to answer the research question: to what extent does a two-day pedagogical workshop intervention by U.S. professors impact teaching and learning practices of participants in two international settings in Kosovo? In this study, Vygotsky's (1978) work on Social Constructivism was used as a theoretical framework to examine the impact of the pedagogical workshop intervention. Vygotsky's concept of the zone of proximal development provided a lens for the social interactions within the workshop as the U.S. professors provided a deeper understanding of pedagogical strategies (student engagement, questioning strategies, formative reflective assessment, and representing to learn).

Future partnerships with each university could provide further opportunity to measure effective professional development. Classroom observations of faculty and pre-service teachers would provide detailed accounts of participants implementing the strategies presented in the workshops. The most effective means of examining student improvement data might be collected pre-workshop and postworkshop. While self-reporting data is the most commonly used data in professional development (Lawless \& Pelligrino, 2007), it is not the most accurate measure of effectiveness. 
One aspect that would need to be taken into consideration in using student data to measure teacher effectiveness cross-culturally would be interpreting student achievement scores on specific assessment measures with carefully (Liu, 2015). Although student achievement data has been used across international settings to analyze teacher effectiveness, these data do not always translate across cultures. As Liu (2015) called for, a culturally embedded conception of achievement and assessment would first need to be established in order to enable international collaboration on professional development.

One of the most effective ways of providing professional development for teachers begins with providing a clear presentation of the theory behind instructional practices (Showers, Joyce, \& Bennett, 1987), which includes a demonstration of the new strategy, with initial practice in the workshop setting. Two of several common features of professional development are shared vision of good teaching and well-defined standards of teaching practice (Darling-Hammond, 1999). In this study, the researchers presented student-centered techniques (Zemelman, Daniels, \& Hyde, 2012) as part of the research-based practices to support a common vision and well-defined standards of teaching practice.

What is missing from this study is the opportunity to provide feedback as participants implement new instructional practices (Showers, Joyce, \& Bennett, 1987). Ideally, the researchers would have coconstructed a checklist with participants of what to watch for in classrooms as participants implemented new strategies. Co-constructing the checklist, as situated within Vygotsky's Social Constructivist Theory (1986), would have provided deeper learning opportunities for the participants, as well as concrete ideas of what implementing the strategies might look like within classrooms. The checklist would have also provided a means for researchers to provide feedback to participants as they implemented the strategies.

Working across international settings for teacher quality is a complex process (Liu, 2015). In this study, the researchers sought to include teachers' voices in their professional growth by working with key leaders at the participating institutions (Goldberg, 2019). Overall, participants found the workshop useful, as demonstrated in the data from the participant survey. Additionally, the participants were reported to have tried new pedagogical strategies based on the workshops.

\section{CONCLUSION}

Overall, most participants agreed or strongly agreed with positive attributes about the workshop training with the highest responses involved the preparedness of the trainers, clearly defined objectives, materials provided, participation and interaction, and usefulness of the training. The lowest response was concerning the meeting room, over which the trainers had no control. One positive comment was, "The topics were relevant and helpful to me." Another participant shared, "Best workshop I have ever had in my professional career." Another stated, "This is the best training I have attended up to now."

The post workshop survey results from University A indicate that the workshop themes (i.e., Student Engagement, Questioning Strategies, Formative Reflective Assessment, and Representing to Learn) were relevant to the participants and were clearly defined during the training.

There is not a similar table for University B. Instead, the researchers discussed the presentations and interactions with student participants at the end of the session. The results were positive. This workshop was their first workshop about instructional strategies. According to the key administrative leader from University B, "They [student participants] enjoyed the workshop very much. Their feedback was incredible. They said that they learned the basics on how to work on their teaching."

Regarding students who had graduated, "The ones who got their jobs said that they already have incorporated some of the teaching techniques and strategies into their own teaching plans." Students 
who have graduated and continued with Master's studies said: "they are finding your workshop very, very useful in a number of courses that they are attending in their Master Degree studies." Student participants shared examples with the key leader from University B that they would be better at engaging students, asking questions, and conducting meaningful assessments in their future teaching.

\section{SUGGESTIONS}

Differences in organizations philosophies, interpersonal relationships, and cultural values can affect collaboration between professionals in international settings (Rudge, 2018). Mutual trust is required. For this study, researchers and participants worked together to build mutually positive, professional relationships. Workshops that were designed collaboratively to have value for the participants to improve their professional practice. Future research might focus on the long-term benefits of such partnerships, especially addressing how the content of the workshops continues to inform their work. At the time of this writing, a follow up professional development workshop is planned with two Kosovo universities with a longer timeframe by the same two U.S. professors providing professional development training in response to topics requested by Kosovo participants.

\section{ACKNOWLEDGEMENTS}

The authors wish to thank Dr. Matt Hayden, Drake University for his leadership in establishing both university partnerships, Drake International Center for travel funds, Vice-Rektor Dr. Mimoza Dushi, and Dr. Sejdi Sejdiu for their energy and commitment to this work.

\section{REFERENCES}

Anfara, Jr., V. A., Brown, K. M., \& Mangione, T. L. (2002). Qualitative analysis on stage: Making the research process more public. Educational Researcher, 31(7), 28-38.

Bogdan, R. C. \& Biklen, S. K. (2007). Qualitative Research for Education (5th ed.). Upper Saddle River, NJ: Pearson Education, Inc

Cadiero-Kaplan, K. (winter, 1999). Integrating technology: Issues for traditional and constructivist pedagogies. Journal of Computing in Teacher Education, 15(2), 14-18.

Christenson, S. L., Reschly, A. L., \& Wylie, C. (2013). Handbook of Research on Student Engagement. Springer, Minneapolis, MN.

Creswell, J. W. (2013). Qualitative Inquiry \& Research Design. (L. Habib, Ed.) (3rd ed.). Thousand Oaks, CA: SAGE Publications.

Daniels, H., Cole, M., \& Wertsch, J. (2011). The Cambridge Companion to Vygotsky. New York, NY: Cambridge University Press.

Darling-Hammond, L. (1999). Teacher quality and student achievement: A review of state policy evidence. Seattle: Center for the Study of Teaching and Policy, University of Washington.

Desimone, L. (2009). Improving impact studies of teachers' professional development: Toward better conceptualizations and measures. Educational Researcher, 38(3), 181-199.

Desimone, L., Poerter, A.C., Garet, M., Yoon, K.S., \& Birman, B. (2002). Effects of professional development on teachers' instruction: Results from a three-year study. Educational Evaluation and Policy Analysis, 24(2), 81-112.

Eltemamy, A. (2019). Developing a programme of support for teacher leadership in Egypt. International Journal of Teacher Leadership, 10(1), 103-115. 
Fiala, M. R. (2018). A multi-case study of private institution undergraduate anatomy and physiology faculty in one Midwest state. Unpublished doctoral dissertation, Drake University, Des Moines, IA.

Growing Kosovo: How the Iowa National Guard created a decades long partnership halfway around the world. (2015). Des Moines Register. Retrieved from htpps://www.desmoinesregister.com/story/news/local/columnists/Courtneycrowder/2018/11/09/growing

Kosovo-iowa-national-guard-partnership-pristina-diplomacy-robert-ray-middle-easverterans/1902997002/

Hattie, J. (2012). Visible Learning for Teachers. New York, NY: Routledge.

Joyce, B.R. \& Showers, B. (2002). Student Achievement Through Staff Development. Alexandria, VA: ASCD.

Joyce, B. (2004). How are professional learning communities created? The Phi Delta Kappan, 86(1), 76-83.

Goldberg, S. (2019). Dewey's ideas in action! Continuing professional development in an international community of practice. Education and Culture, 35(1), 75-100.

Fink, A. (2013). How to Conduct Surveys. (V. Knight, Ed.) (5th ed.). Thousand Oaks, CA: SAGE Publications, Inc.

Knowles, M.S. \& Swanson, R.A. (2015). The adult learner: The definitive classic in adult education and human resource development. New York, NY: Routledge.

Lawless, K. \& Pellegrino, J. (2007). Professional development in integrating technology into teaching and learning: Knowns, unknowns, and ways to pursue better questions and answers. Review of Educational Research, 77(4), 575-614. Retrieved from https://doi.org/10.3102/0034654307309921

Likaj, R. (2016). Continuing professional development for vocational teachers and trainers in Kosovo. Kosovo: European Training Foundation.

Likert, R. (1932). A Technique for the measurement of attitudes. Archives of Psychology, 140, 1-55.

Liu L.B. (2015) Teacher Educator Quality and Professional Development in an Era of Globalization. In: Teacher Educator International Professional Development as Ren. New Frontiers of Educational Research. Springer, Berlin: Heidelberg

Marzano, R. (2010). The art and science of teaching: Representing knowledge non-linguistically. Educational Leadership, 67(8), 84-86.

Marzano, R. (2012). Art and science of teaching: Writing to learn. Educational Leadership, 69(5), 8283.

Oleson, H. \& Hora, M.T. (2013). Teaching the way they were taught? Revisiting the sources of teaching knowledge and the role of prior experience in shaping faculty teaching practices. High Education. Springer Science+Business Media Dordrecht. DOI 10.1007/s10734-013-9678-9

Qanay, G., Anderson-Payne, E., Ball, S., Barnett, P., Kurmankalova, K., Mussarova, V., Kenzhetayeva, G. \& Tanayeva, A. (2019). Developing teacher leadership in Kazakhstan. International Journal of Teacher Leadership, 10(1), 53-64. 
Phondej, Wanida \& Kittisarn, Akkapong \& Neck, Philip. (2010). The seven steps of case study development: A strategic qualitative research methodology in female leadership. Review of International Comparative Management, 11, 52-65

Qualtrics Labs. (2013). Qualtrics [Computer software]. Provo, UT: Author.

Republic of Kosovo: Sister States Relationship EST. 2013. (2020). Iowa Sister States. Retrieved 01 November, 2019 from https://www.iowasisterstates.org/kosovo

Richetti, C. \& Sheerin, J. (1999, November). Helping students ask the right questions. Educational Leadership, 58-62.

Rudge, L. (2018). A self-study of factors affecting the collaboration between university and school professionals. International Journal of Teacher Education and Professional Development, 1(1), 2135.

Sadler, D.R. (1998). Formative assessment: Revisiting the territory. Assessment in Education, 5(1), 77-84.

Salmons, J. (2015). Qualitative online interviews. Thousand Oaks, CA: Sage.

Seidman, I. (2013). Interviewing as qualitative research (4th ed.). New York, NY: Teachers College Press.

Sousa, D.A. (2006). How the brain learns (3rd ed.). Thousand Oaks, CA: Corwin.

Sternberg, R.J. (October, 1999). Answering questions and questioning answers. Phi Delta Kappan, 76(2), 136-138.

Tate, M. (2012). Sit and Get Won't Grow Dendrites. Thousand Oaks, CA: Corwin

Traver, R. (March, 1998). What is a good guiding question. Educational Leadership, 70-75.

Vygotsky, L. (1986). Thought and language (Alex Kozulin, Trans.). Cambridge: MIT Press.

Vygotsky, L. (1978). Mind in Society: The Development of Higher Psychological Processes. Cambridge, MA: Harvard University Press.

What Wolfe, P. (2001). Brain matters: Translating research into classroom practice. Alexandria, VA: Association for Supervision and Curriculum Development.

Weimer, M. (2002). Learner-centered teaching: Five key changes to practice. San Francisco, CA: Jossey-Bass.

Yin, R. K. (2016). Qualitative research from start to finish (2nd ed.). New York, NY: The Guilford Press.

Zemelman, S., Daniels, H.S. \& Hyde, A. (2012). Best practice: Bringing standards to life in America's Classrooms. (4th ed.). Portsmouth, NH: Heinemann. 